\title{
Analisis Kriteria Sistem Jaminan Halal pada Produksi Susu di PT. Greenfields Indonesia Tahun 2019
}

\author{
Siti Hartina ${ }^{1 *}$, Ach. Syahrir $^{1}$ dan Ria Ramadhani Dwi Atmaja ${ }^{1}$ \\ ${ }^{1}$ Jurusan Farmasi, Fakultas Kedokteran dan Ilmu Kesehatan, UIN Maulana Malik Ibrahim, Malang, Indonesia \\ *E-mail: tinaatinn@gmail.com
}

\begin{abstract}
World demand for halal pharmaceutical products, which include food, cosmetics, drugs, and other products will continue to grow with the increasing of global Moslems population in the world. Milk is one of the pharmaceutical products produced from livestock commodities. It is processed into 2 types of products namely ESL and UHT milk. In Indonesia, the halal status of a product is a crucial point for consumers who are predominantly by Moslems. In its processing, Indonesian Ulema Council (MUI) has a rule called HAS 23101, a halal certification requirement as an implementation of Halal Guarantee System. This study examines the importance of the Halal Assurance System criteria in milk production in the Indonesian food industry. The purpose of this study is to analyse the suitability of the halal guarantee system criteria for milk production in PT. Greenfields Indonesia based on HAS 23101 standards. This research is a descriptive observational study. The data collection process is carried out by providing a checklist to the halal management team in the food industry. The results obtained are the percentage of conformity to the 100\% Halal Policy, 100\% Halal Management Team, 100\% Training and Education, 100\% Material, 100\% Product, 91.6\% Product Facility, Written Procedure for Critical Activity 100\%, 100\% Search Capability, Products that do not meet $77.8 \%$ criteria, $100 \%$ internal audit, and $100 \%$ management review. The percentage of conformity results obtained as a whole was $97.2 \%$.
\end{abstract}

Keywords: Halal Products, Halal Guarantee System, Milk

\section{ABSTRAK}

Permintaan dunia untuk produk farmasi halal, yang meliputi makanan, kosmetik, obat, dan produk lainnya akan terus tumbuh dengan meningkatnya populasi global, terutama umat muslim di dunia. Susu merupakan salah satu produk farmasi yang dihasilkan dari komoditas peternakan. Susu diolah menjadi 2 jenis produk yaitu susu ESL dan UHT. Di Indonesia, status kehalalan sebuah produk merupakan titik krusial bagi konsumennya yang mayoritas muslim. Dalam pengolahannya, MUI mempunyai aturan yang disebut HAS 23101. HAS 23101 adalah persyaratan sertifikasi halal dalam upaya menerapkan Sistem Jaminan Halal. Studi ini mengkaji tentang pentingnya kriteria Sistem Jaminan Halal pada produksi susu di industri pangan yang ada di Indonesia. Tujuan studi ini adalah untuk menganalisis kesesuaian dari kriteria Sistem Jaminan Halal pada produksi susu di PT. Greenfields Indonesia dengan standar HAS 23101. Penelitian ini merupakan penelitian observasional yang bersifat deskriptif. Proses pengumpulan data dilakukan dengan cara memberikan daftar checklist kepada tim manajemen halal di industri pangan tersebut. Hasil penelitian didapatkan persentase kesesuaian pada Kebijakan Halal 100\%, Tim Manajemen Halal 100\%, Pelatihan dan Edukasi 100\%, Bahan 100\%, Produk 100\%, Fasilitas Produk 91,6\%, Prosedur Tertulis untuk Aktivitas Kritis 100\%, Kemampuan Telusur 100\%, Penganan Produk yang Tidak Memenuhi Kriteria 77,8\%, Audit Internal 100\%, dan Kaji Ulang Manajemen 100\%. Hasil persentase kesesuaian yang didapatkan secara keseluruhan sebesar 97,2 persen.

Kata kunci: Produk Halal, Sistem Jaminan Halal, Susu 


\section{Pendahuluan}

Pada dasarnya permintaan dunia untuk produk halal, yang meliputi makanan, kosmetik, obat, layanan, dan produk lainnya akan terus tumbuh dengan peningkatan populasi global, terutama umat Muslim di dunia. Diperkirakan bahwa pada tahun 2030, populasi Muslim akan mencakup 27\% dari populasi global. Industri-industri makanan di Indonesia telah mengalami peningkatan yang sangat siginifikan seiring dengan perkembangan ilmu pengetahuan dan teknologi (Ahmad, 2016). Peningkatan produksi makanan selain memberikan kemudahan bagi masyarakat untuk mengkonsumsinya, ternyata juga menimbulkan kekhawatiran dan keresahan baru terkait dengan kualitas produk makanan jika ditinjau dari aspek kehalalannya.

Halal merupakan sebuah aturan dalam agama Islam, yang digunakan untuk menyatakan bahwa sesuatu hal diijinkan atau dilarang untuk dikonsumsi oleh umat muslim dengan dasar dari Al-Qur'an, hadist, atau ijtihad (kesepakatan ulama) (Salehudin, 2010). Konsep halal diberikan apresiasi tinggi karena produk halal dianggap sebagai produk yang lebih sehat, lebih bersih, dan lebih lezat. Konsep halal ini tidak hanya popular diantara umat muslim, tetapi juga di masyarakat dunia secara umum dan mulai diterapkan pada berbagai jenis produk seperti pada makanan, minuman dan obat-obatan (Lada dkk., 2009).

Indonesia adalah negara dengan mayoritas muslim. Negara harus menjamin setiap pemeluk agama untuk menjalankan syariat agamanya, termasuk jaminan produk halal. Sebagaimana diatur dalam Undang-Undang Nomor 33 Tahun 2014 tentang Jaminan Produk Halal (UU JPH), Undang-Undang ini sebagai landasan hukum memberikan perlindungan hukum kepada konsumen muslim terhadap ketidakpastian penggunaan berbagai produk makanan dan minuman halal baik dalam bentuk barang dan jasa sesuai dengan kewajiban hukum Islam.

Susu merupakan salah satu produk minuman yang dihasilkan dari komoditas peternakan. Kandungan gizi susu yang lengkap serta nilai ekonomis susu dapat memberikan kontribusi yang signifikan bagi pemenuhan kebutuhan gizi, maupun peningkatan kesejahteraan masyarakat (Usmiyati dan Abubakar, 2009). Sebagian besar produksi susu dimanfaatkan untuk proses pengolahan lebih lanjut menjadi produk susu olahan. Susu olahan yang dikonsumsi harus mempunyai angka kecukupan gizi seperti yang diatur dalam UndangUndang Nomor 9 Tahun 2016 Tentang Acuan Label Gizi. Susu UHT (Ultra High Temperature) dan susu ESL (Extended Self Life) adalah susu olahan yang sering dikonsumsi oleh masyarakat. Susu olahan harus mempunyai mutu yang terstandar dan aman.
HAS 23101 adalah pedoman pemenuhan kriteria sistem jaminan halal di industri pengolahan. Industri pengolahan pangan di Indonesia harus melakukan Sistem Jaminan Halal. Sistem Jaminan Halal adalah suatu sistem manajemen yang disusun, diterapkan dan dipelihara oleh perusahaan pemegang sertifikat halal untuk menjaga kesinambungan proses produksi halal sesuai dengan ketentuan LPPOM MUI (LPPOM, 2018). Sistem Jaminan Halal menghasilkan Jaminan Produk Halal yang penting dalam kemajuan ilmu pengetahuan dan teknologi dibidang pangan, obat-obatan, dan kosmetik berkembang pesat.

Khususnya bagi konsumen Indonesia yang mayoritas beragama muslim, jika tidak ada sertifikat halal dan jaminan halal maka banyak konsumen yang akan meragukan kehalalannya. Jika itu terjadi, maka akan ada kekhawatiran yang mengakibatkan masalah pada kesehatan, terancamnya nyawa dan kepercayaan konsumen terhadap produk juga akan berkurang (Dewi, 2007). Berdasarkan kondisi tersebut, maka perlu diselenggarakan kajian terkait analisis pada Sistem Jaminan Halal di Indonesia. Karena kehalalan adalah parameter utama dalam hal preferensi atas suatu produk. Pada penelitian ini pembahasan difokuskan pada kriteria-kriteria Sistem Jaminan Halal yang telah dilakukan oleh PT. Greenfields Indonesia. Tujuan dari penelitian ini adalah menganalisis hasil kesesuaian dari kriteria-kriteria sistem jaminan halal pada produksi susu di PT. Greenfields Indonesia dengan standar HAS 23101. Penelitian ini diharapkan dapat menjadi khazanah dalam kajian produksi, pengembangan, dan pemasaran produk halal di Indonesia.

\section{Metode Penelitian}

Penelitian ini dilakukan pada bulan bulan Februari 2019 di Kabupaten Malang dengan menggunakan instrumen berupa daftar checklist HAS 23101. Teknik pengambilan data dengan metode purposive sampling. Objek penelitian sebanyak 3 orang respoden tim Audit Halal Internal (AHI) PT. Greenfields Indonesia. Penelitian ini menggunakan metode kualitatif yang di kuantifikasi.

Penjelasan kerangka konseptual di mulai dari pendekatan sistem terhadap kriteria SJH tersusun dari salah satu industri pengolahan pangan di Indonesia yang produk utama adalah susu. Susu olahan yang dihasilkan ada dua jenis, yaitu UHT (Ultra High Temperature) dan ESL (Extended Self Life). Untuk menghindari keragu-raguan dalam mengkonsumsi atas kehalalannya, dibutuhkan Sistem Jaminan Halal dalam produksinya. Sistem Jaminan Halal merupakan salah satu bagian penting dalam standar produksi susu yang akan dikonsumsi masyarakat, keberadaannya dibutuhkan untuk menjamin kehalalan dalam suatu produk. Meskipun jenis susu di industri pangan ini ada 2 macam, tetapi dalam melaksanakan Sistem Jaminan Halal keduanya menjadi satu manajemen. Di dalam sistem jaminan halal ini ada beberapa kriteria (input), meliputi: kebijakan halal, tim manajemen halal, training dan edukasi, bahan, produk, fasilitas produk, 
prosedur tertulis untuk aktifitas kritis, kemampuan telusur (traceability), penanganan produk yang tidak memenuhi kriteria, internal audit, dan kaji ulang management. Kemudian untuk prosesnya digunakan HAS 23101 (standar pemenuhan kriteria SJH di industri pengolahan) untuk menilai seberapa besar persentase dari tiap-tiap kriteria yang ada pada Sistem Jaminan Halal. Output yang didapatkan adalah hasil kesesuaian dari masing-masing kriteria Sistem Jaminan Halal.

\section{Hasil dan Pembahasan}

Jaminan halal yang dilakukan oleh industri makanan merupakan suatu kewajiban dalam memenuhi tanggung jawab kepada LPPOM MUI atas sertifikat jaminan halal yang diperolehnya dan konsumen sebagai penikmat dari produk yang telah dihasilkan. Sistem Jaminan Halal merupakan manajemen yang disusun oleh sebuah perusahaan untuk menjaga konsistensinya dalam memproduksi produk halal yang sesuai dengan ketentuan LPPOM MUI yang berlaku (MUI, 2018). Dalam menjaga konsistensinya, LPPOM MUI mempunyai ketentuan dengan kriteria-kriteria tertentu yang sesuai dengan HAS 23101. Pada penelitian ini, disajikan 11 indikator terhadap sistem jaminan halal. Daftar checklist dari masing-masing indikator dijelaskan pada Tabel 1-11. Hasil pengolahan data menunjukkan bahwa keseluruhan persentase kesesuaian Sistem Jaminan Halal yang dilakukan oleh PT. Greenfields Indonesia memperoleh persentase sebesar 97,2 persen.

\subsection{Kebijakan Halal}

Kebijakan halal adalah pernyataan tertulis komitmen manajemen puncak untuk senantiasa menghasilkan produk halal secara konsisten (MUI, 2018). Kebijakan halal diperoleh persentase kesesuaian sebesar $100 \%$. Hal ini menunjukkan bahwa PT. Greenfields Indonesia telah berkomitmen menghasilkan produk halal dengan perwujudan motto yang berbunyi: "Gigih dalam menghasilkan produk susu yang berkualitas, halal, aman dikonsumsi, berwawasan lingkungan dan mematuhi peraturan yang berlaku. Inovatif dan kreatif dalam memelihara dan mengembangkan Sistem Manajemen Keamanan Pangan \& Sistem Jaminan Halal serta lingkungan". PT. Greenfields Indonesia juga menjamin seluruh produk yang dibuat untuk pasar Indonesia telah disertifikasi oleh LPPOM MUI.

\subsection{Tim Manajemen Halal}

Dalam memenuhi kriteria Sistem Jaminan Halal (SJH), diperlukan suatu kelompok orang yang bertanggung jawab terhadap perancanaan, implementsi, evaluasi dan perbaikan SJH diperusahaan (MUI, 2018). Sekelompok orang ini disebut dengan Tim Manajemen Halal. Tim Manajemen Halal telah ditetapkan dan ada bukti penunjukannya diperoleh persentase kesesuaian sebesar $100 \%$. Bukti penunjukan terdapat pada surat tugas dengan nomor: GI/MP/ST/QAD/01/1/18.

\subsection{Pelatihan dan Edukasi}

Pelatihan merupakan kegiatan yang diselenggarakan dan memiliki tujuan untuk meningkatkan pengetahuan (knowledge), keterampilan (skill), dan/atau perilaku (attitude) dari semua personel yang terlibat aktivitas kritis (MUI, 2018). Industri makanan harus memiliki prosedur tertulis pelaksanaan pelatihan. Pelatihan yang dilakukan harus memiliki materi yang meliputi HAS 23101. Sebelum melakukan perlatihan sertifikasi halal, perwakilan perusahaan harus telah mengikuti pelatihan eksternal. Hal tersebut dilakukan dengan tujuan agar trainer dari internal dapat memahami kriteria sertifikasi halal dengan benar. PT. Greenfields Indonesia menjadi salah satu industri makanan pemegang sertifikat halal dan telah mengikuti pelatihan di LPPOM MUI, maka dilakukan pelatihan eksternal sekurangkurangnya 2 tahun sekali karena itu persentase kesesuaian yang dihasilkan sebesar $100 \%$.

\subsection{Bahan}

Bahan adalah unsur yang digunakan untuk membuat atau menghasilkan Produk. Bahan baku yang digunakan dalam proses pembuatan susu terdiri dari bahan baku, bahan tambahan dan penolong. Bahan baku adalah seluruh bahan yang digunakan dalam proses pembuatan produk dan menjadi bagian dari komposisi produk (ingredient) (MUI, 2018). Bahan baku utama yang digunakan dalam proses pembuatan susu di PT. Greenfields Indonesia adalah susu sapi segar jenis Frissian Holstein yang didatangkan dari Australia. Bahan baku tambahan yang digunakan dalam produksi susu diantaranya gula pasir, Anhydrous Milk Fat (AMF) atau minyak kelapa sawit, bubuk skim, Stabilizer Recodan SU 182, garam, Choco Flavor F-6351, bubuk kuning telur, emulsifier, ekstrak malt, perisa strowberi, mocachino, dan vanilla, serta pewarna. Bahan baku penolong yang digunakan dalam proses pembuatan susu yaitu air yang khusus digunakan proses (air proses). Persentase kesesuaian yang di peroleh pada Bahan sebesar $100 \%$ karena mempunyai dokumen pendukung yang memadai seperti dokumen karakteristik Raw Material yang berisi nama bahan, deskripsi bahan, informasi nutrisi dan komposisi, karakteristik keamanan pangan (biologi, kimia, dan fiisika), metode produksi, umur simpan, kondisi penyimpanan, kemasan, informasi pada label (kaitan food safety, handling dan preparasi), metode distribusi, dan supplier (nama dan lokasi). Terdapat juga sertifikat halal, diagram alir proses, MSDS dan kombinasi dari beberapa dokumen lainnya.

\subsection{Produk}

Produk adalah produk yang didaftarkan untuk disertifikasi, mencakup produk antara/intermediet dan produk akhir, baik 
yang dijual eceran (retail) atau curah (MUI, 2018). Nama produk di PT. Greenfields Indonesia yang disertifikasi tidak menggunakan nama yang mengarah pada sesuatu yang diharamkan atau ibadah yang tidak sesuai syariah islam misalnya Susu ESL Skimmed Milk. Produk di PT. Greenfields Indonesia juga memiliki bau dan rasa yang tidak mengarah pada produk haram atau yang telah dinyatakan haram berdasarkan fatwa MUI. Daftar Bahan susu yang disetujui oleh LPPOM MUI di PT. Greenfields Indonesia kandungan bahan tidak ada yang mengarah ke arah haram. Karena dari masing-masing bahan telah diperoleh Sertifikat Halal maka dari itu persentase kesesuaian yang diperoleh sebesar $100 \%$.

\subsection{Fasilitas Produk}

Fasilitas produk adalah semua lini produksi dan peralatan pembantu yang digunakan untuk menghasilkan produk, baik milik perusahaan sendiri atau menyewa dari pihak lain (MUI, 2018). PT. Greenfields Indonesia pada fasilitas produksi tidak melakukan penambahan dan tidak menggunakan tempat maklon, maka tidak ada produksi yang digunakan secara bergantian dengan bahan-bahan yang mengandung babi/turunannya. Fasilitas produksi di PT. Greenfields Indonesia juga terbebas dari najis dan dilengkapi dengan fasilitas sanitasi seperti fasilitas cuci tangan dan toilet. Proses produksi susu UHT dan ESL tidak terdapat alat yang mengandung bahan najis/haram seperti babi dan turunannya, karena terdapat misunderstanding dengan responden maka persentase kesesuaian yang diperoleh sebesar 91,6\%.

\subsection{Prosedur Tertulis untuk Aktivitas Kritis}

Prosedur tertulis aktivitas kritis adalah seperangkat tata cara kerja yang dibakukan untuk mengendalikan aktivitas kritis (MUI, 2018). Terdapat beberapa prosedur dalam aktivitas kritis yaitu Prosedur Seleksi Bahan Baru, Prosedur Pembelian, Prosedur Formulasi Produk/Pengembangan Produk Baru, Prosedur Pemeriksaan Barang Datang, Prosedur Produksi, Prosedur Pencucian Fasilitas Produksi dan Peralatan Pembantu, Prosedur Penyimpanan dan Penanganan Bahan/Produk, dan Prosedur Transportasi. Masing-masing dari setiap prosedur diperoleh persentase kesesuaian sebesar $100 \%$. Karena pada tiap prosedur telah terlaksana sesuai dengan peraturan HAS 23101.

\subsection{Kemampuan Telusur (Traceability)}

Kemampuan telusur (traceability) adalah kemampuan telusur produk yang disertifikasi berasal dari bahan yang memenuhi kriteria (disetujui LPPOM MUI) dan diproduksi di fasilitas produksi yang memenuhi kriteria (bebas dari bahan babi/turunannya) (MUI, 2018). Produk yang disertifikasi dapat tertelusur berasal dari bahan yang disetujui LPPOM MUI dan diproduksi di fasilitas produksi yang bebas dari babi/turunannya diperoleh, bahan dengan kode yang sama selalu mempunyai status halal yang sama, informasi bahan tertelusur pada semua kegiatan kritis, bahan yang repacked/relabeled (jika ada) tertelusur identitas aslinya, dan ketersediaan bukti ketertelusuran produk di PT. Greenfields Indonesia diperoleh persentase kesesuaian sebesar $100 \%$.

\subsection{Penanganan Produk yang Tidak Memenuhi Kriteria}

Produk yang tidak memenuhi kriteria adalah produk bersertifikat halal yang terlanjur dibuat dari bahan yang tidak disetujui LPPOM MUI dan /atau diproduksi di fasilitas yang tidak bebas dari bahan babi/turunannya (MUI, 2018). Produk yang tidak memenuhi kriteria disimpan terpisah dan diberi tanda khusus sebelum dilakukan penanganan. Penanganan produk dapat berupa pemusnahan produk, penjualan untuk tujuan non pangan, penjualan ke negara non muslim, dan lainnya. Penganan produk tidak berupa proses ulang (rework). Bila dilakukan penjualan ke konsumen yang tidak mempersyaratkan produk halal maka tidak boleh ada penandaan produk halal, misalnya dengan mencantumkan logo halal di kemasan dan melampirkan Sertifikat Halal sebagai dokumen pendukung produk. Produk yang tidak memenuhi kriteria tidak boleh diedarkan ke masyarakat, baik dalam rangka promosi, sumbangan, dan lainnya. Prosedur penarikan produk dapat dituliskan tersendiri atau terintergrasi dengan prosedur sistem yang lain. Setelah dilakukan penarikan produk, produk yang tidak memenuhi kriteria dapat ditangani mengikuti alur. Persentase kesesuaian yang diperoleh sebesar $77,8 \%$ karena 2 responden di antaranya menjawab dengan jawaban berbeda pada poin produk yang tidak memenuhi kriteria dan terlanjur dijual, sudah dilakukan penarikan produk (recall). Pada faktanya, PT. Greenfields Indonesia tidak terdapat produk yang tidak memenuhi kriteria.

\subsection{Audit Internal}

Audit internal adalah audit yang dilakukan oleh tim manajemen halal untuk menilai kesesuaian penerapan SJH di perusahaan dengan persyaratan sertifikasi halal MUI (MUI, 2018). UU Nomor 33 Tahun 2014 menyebutkan bahwa perusahaan harus mempunyai prosedur tertulis audit internal pelaksanaan SJH. Audit internal dilakukan secara terjadwal setidaknya 6 bulan sekali atau lebih sering jika diperlukan. Auditor halal internal harus pernah mengikuti pelatihan HAS 23000 (persyaratan sertifikasi halal) yang dilaksanakan secara internal atau eksternal. Audit internal dapat dilakukan secara terpisah atau digabungkan dengan audit internal untuk kebutuhan sistem lain. Batas waktu untuk tindakan koreksi diberikan selama 1 bulan. Hasil audit internal disampaikan ke pihak yang bertanggung jawab dan tindakan koreksi diperlukan sesuai batas waktu yang ditentukan. Hasil audit internal disampaikan ke LPPOM MUI dalam bentuk laporan berkala setiap 6 bulan sekali. Bukti audit internal yang terdapat di PT. Greenfields Indonesia dalam bentuk dokumen. Persentase kesesuaian diperoleh sebesar $100 \%$.

\subsection{Kaji Ulang Manajemen}

Kaji ulang manajemen adalah kajian yang dilakukan oleh manajemen puncak atau wakilnya dengan tujuan untuk 
menilai efektifitas penerapan SJH dan merumuskan perbaikan berkelanjutan (MUI, 2018). Kaji ulang manajemen dilakukan secara terjadwal setidaknya satu tahun sekali dan dihadiri oleh manajemen puncak/MR. Kaji ulang manajemen disampaikan ke pihak yang bertanggung jawab (ditindaklanjuti), tindak lanjut hasil evaluasi sudah menetapkan batas waktu (jika ada), tindak lanjut hasil evaluasi sesuai dengan batas waktu yang sudah ditetapkan dan sesuai dengan hasil kaji ulang manajemen, kemudian dilakukan identifikasi penyebab kelemahan dan ditindak lanjuti, dan ketersediaan bukti pelaksanaan kaji ulang manajemen diperoleh persentase kesesuaian sebesar $100 \%$.

Tabel 1

Indikator pada Kebijakan Halal

\begin{tabular}{|c|c|c|}
\hline No & Indikator & $\%$ Kesesuaian \\
\hline 1 & Ketersediaan kebijakan halal & $100 \%$ \\
\hline 2 & Sosialisasi kebijakan halal ke seluruh stakeholder perusahaan & $100 \%$ \\
\hline \multirow[t]{2}{*}{3} & Ketersediaan bukti social kebijakan halal & $100 \%$ \\
\hline & & $100 \%$ \\
\hline
\end{tabular}

Sumber: Data Primer (2019), diolah

Tabel 2

$\underline{\text { Indikator pada Tim Manajemen Halal }}$

\begin{tabular}{clc}
\hline No & \multicolumn{1}{c}{ Indikator } & $\%$ Kesesuaian \\
\hline 1 & Penetapan Tim Manajemen Halal dan bukti penunjukannya & $100 \%$ \\
2 & Tim mencakup semua bagian aktivitas kritis. & $100 \%$ \\
3 & Kompetensi dan wewenang yang dibutuhkan tim & $100 \%$ \\
4 & Sumberdaya tim yang memadai untuk menjalankan tugas & $100 \%$ \\
5 & Tim mengikuti persyaratan sertifikasi MUI & Total Persentase Keseluruhan \\
\hline
\end{tabular}

Sumber: Data Primer (2019), diolah

Tabel 3

Indikator pada Pelatihan dan Edukasi

\begin{tabular}{llr} 
No & \multicolumn{1}{c}{ Indikator } & $\%$ Kesesuaian \\
\hline 1 & Pelatihan eksternal tim minimal dua tahun sekali & $100 \%$ \\
2 & Pelatihan internal dilaksanakan setahun sekali & $100 \%$ \\
3 & Pelatihan internal untuk semua karyawan terkait aktivitas kritis & $100 \%$ \\
4 & Materi pelatihan internal sesuai dengan HAS 23000 & $100 \%$ \\
5 & Ketersediaan bukti evaluasi hasil pelatihan internal & $100 \%$ \\
6 & Tersimpannya bukti pelaksanaan pelatihan & $100 \%$ \\
7 & Ketersediaan bukti edukasi dalam menerapkan SJH & $100 \%$ \\
\hline & & Total Persentase Keseluruhan \\
\hline
\end{tabular}

Sumber: Data Primer (2019), diolah

Tabel 4

Indikator pada Bahan

\begin{tabular}{|c|c|c|}
\hline No & Indikator & $\%$ Kesesuaian \\
\hline 1 & Bahan dengan dokumen pendukung dan valid & $100 \%$ \\
\hline 2 & Persetujuan daftar bahan oleh LPPOM MUI & $100 \%$ \\
\hline 3 & Pembaharuan daftar bahan & $100 \%$ \\
\hline & & $100 \%$ \\
\hline
\end{tabular}

sumber: Data Primer (2019), diolah 
Tabel 5

Indikator pada Produk

\begin{tabular}{|c|c|c|}
\hline No & Indikator & $\%$ Kesesuaian \\
\hline 1 & Nama produk yang tidak sesuai dengan syariah islam & $100 \%$ \\
\hline 2 & Produk tidak memiliki bau atau rasa mengarah ke produk haram & $100 \%$ \\
\hline 3 & $\begin{array}{l}\text { Khusus produk retail, adanya produk baru merk yang sama dengan merk produk yang telah } \\
\text { disertifikasi }\end{array}$ & $100 \%$ \\
\hline \multirow[t]{2}{*}{4} & Poin sebelumnya Ya, disertifikasinya produk baru. & $100 \%$ \\
\hline & Total Persentase Keseluruhan & $100 \%$ \\
\hline
\end{tabular}

sumber: Data Primer (2019), diolah

Tabel 6

Indikator pada Fasilitas Produk

\begin{tabular}{|c|c|c|}
\hline No & Indikator & $\%$ Kesesuaian \\
\hline 1 & Penambahan fasilitas produk & $100 \%$ \\
\hline 2 & Jika Ya, fasilitas tersebut telah terdaftar untuk audit & $100 \%$ \\
\hline 3 & $\begin{array}{l}\text { Jika terdapat bahan babi/turunannya, bahan tidak ditangani dengan fasilitas yang sama dengan } \\
\text { fasilitas yang telah disertifikasi. }\end{array}$ & $100 \%$ \\
\hline 4 & Fasilitas produksi terbebas dari najis dan dilengkapi fasilitas sanitasi & $100 \%$ \\
\hline 5 & Tidak terdapat peralatan produksi yang terbuat dari bahan haram/najis & $33,3 \%$ \\
\hline 6 & $\begin{array}{l}\text { Pencucian fasilitas produk yang digunakan menangani bahan dari babi/turunannya dilakukan } \\
\text { dengan sesuai persyaratan }\end{array}$ & $100 \%$ \\
\hline 7 & Tempat fasilitas pencucian terpisah dari bahan babi/turunannya & $100 \%$ \\
\hline \multirow[t]{2}{*}{8} & $\begin{array}{l}\text { Teknik pengambilan sampel bahan dan produk terjamin tidak terkontaminasi dengan bahan } \\
\text { najis/haram }\end{array}$ & $100 \%$ \\
\hline & $\begin{array}{ll} & \text { Total Persentase Keseluruhan } \\
\end{array}$ & $91,6 \%$ \\
\hline
\end{tabular}

sumber: Data Primer (2019), diolah

Tabel 7

Indikator pada Prosedur Tertulis untuk Aktivitas Kritis

\begin{tabular}{|c|c|c|}
\hline No & Indikator & $\%$ Kesesuaian \\
\hline \multirow[t]{4}{*}{1} & Prosedur Seleksi Bahan & \\
\hline & Penggunaan bahan baru untuk produk yang disertifikasi & $100 \%$ \\
\hline & Jika Ya, bahan baru tersebut mendapat persetujuan LPPOM MUI & $100 \%$ \\
\hline & Ketersediaan bukti seleksi bahan baru & $100 \%$ \\
\hline \multirow[t]{3}{*}{2} & Prosedur Pembelian & \\
\hline & Bahan yang dibeli disetujui oleh LPPOM MUI & $100 \%$ \\
\hline & Ketersediaan bukti pembelian bahan & $100 \%$ \\
\hline \multirow[t]{4}{*}{3} & Prosedur Formulasi Produk/Pengembangan Produk Baru & \\
\hline & Ketersediaan formula baku tertulis & $100 \%$ \\
\hline & Semua bahan telah disetujui LPPOM MUI & $100 \%$ \\
\hline & Ketersediaan bukti formulasi produk/pengembangan produk baru & $100 \%$ \\
\hline \multirow[t]{6}{*}{4} & Prosedur Pemeriksaan Bahan Datang & \\
\hline & Kesesuaian label bahan dengan informasi dilabel yang tertera dalam dokumen bahan & $100 \%$ \\
\hline & Ketersediaan logo halal pada saat penerimaan bahan & $100 \%$ \\
\hline & Kesesuaian informasi antara dokumen bahan dan label halal & $100 \%$ \\
\hline & Jika Tidak, adanya penanganan pada bahan yang sesuai & $100 \%$ \\
\hline & Ketersediaan bukti pemeriksaan bahan datang & $100 \%$ \\
\hline \multirow[t]{4}{*}{5} & Prosedur Produksi & \\
\hline & Persetujuan LPPOM MUI pada penggunaan bahan dalam seluruh tahapan produksi & $100 \%$ \\
\hline & Persamaan formula/resep pada saat produksi dengan formula baku & $100 \%$ \\
\hline & Ketersediaan bukti produksi & $100 \%$ \\
\hline
\end{tabular}


Kemampuan dalam menghilangkan kotoran dan najis pada saat pencucian fasilitas produksi $\quad 100 \%$ dan peralatan

Bukan termasuk bahan najis bahan pembantu dalam pencucian fasilitas produksi $100 \%$

Dilakukan verifikasi organoleptik setelah pencucian untuk membuktikan hilangnya najis $\quad 100 \%$

Ketersediaan bukti pencucian fasilitas dan peralatan pembantu $\quad 100 \%$

$7 \quad$ Prosedur Penyimpanan dan Penanganan Bahan/Produk

Tidak terjadi kontaminasi bahan najis selama penyimpanan di gudang utama dan gudang $\quad 100 \%$ antara

Ketersediaan bukti penyimpanan bahan/produk

$100 \%$

$8 \quad$ Prosedur Transportasi

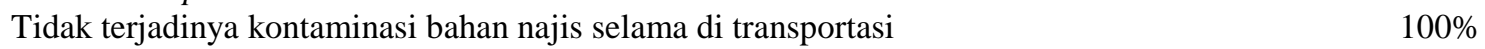

$\begin{array}{ll}\text { Ketersediaan bukti tidak terjadi kontaminasi selama di transportasi } & 100 \%\end{array}$

Total Persentase Keseluruhan $\quad 100 \%$

sumber: Data Primer (2019), diolah

Tabel 8

Indikator pada Kemampuan Telusur

$\begin{array}{llr}\text { No } & \text { Indikator } & \% \text { Kesesuaian }\end{array}$

\begin{tabular}{lll}
\hline 1 & Produk yang disertifikasi dapat tertelusur & $100 \%$ \\
2 & Kesamaan dalam pengkodean bahan mempunyai status halal yang sama & $100 \%$ \\
3 & Terdapat informasi tertelusur pada semua kegiatan kritis. & $100 \%$ \\
4 & Ketertelusuran identitas asli pada bahan repacked/relabeled (jika ada) & $100 \%$ \\
5 & Ketersediaan bukti ketertelusuran produk & Total Persentase Keseluruhan \\
\hline
\end{tabular}

sumber: Data Primer (2019), diolah

Tabel 9

Indikator pada Penanganan Produk yang Tidak Memenuhi Kriteria

\begin{tabular}{|c|c|c|}
\hline No & Indikator & $\%$ Kesesuaian \\
\hline 1 & $\begin{array}{l}\text { Terdapat produk yang tidak memenuhi kriteria, produk tidak diproses ulang atau tidak dijual } \\
\text { ke konsumen yang memerlukan produk halal }\end{array}$ & $100 \%$ \\
\hline 2 & Penarikan produk (recall) pada produk yang tidak memenuhi kriteria dan terlanjur dijual & $33,3 \%$ \\
\hline 3 & Ketersediaan bukti penanganan produk yang tidak memenuhi kriteria & $100 \%$ \\
\hline
\end{tabular}

sumber: Data Primer (2019), diolah

Tabel 10

Indikator pada Audit Internal

\begin{tabular}{|c|c|c|}
\hline No & Indikator & $\%$ Kesesuaian \\
\hline 1 & Dilakukannya audit internal halal setiap 6 bulan sekali & $100 \%$ \\
\hline 2 & Auditor internal telah mengikuti pelatihan eksternal atau internal dengan materi HAS 23000 & $100 \%$ \\
\hline 3 & Auditor internal independen terhadap area yang diaudit & $100 \%$ \\
\hline 4 & $\begin{array}{l}\text { Penyampaian hasil audit ke pihak yang bertanggung jawab terhadap setiap kegiatan yang } \\
\text { diaudit }\end{array}$ & $100 \%$ \\
\hline 5 & Penetapan tindakan koreksi dan batas waktu & $100 \%$ \\
\hline 6 & Tindakan koreksi mampu menyelesaikan kelemahan dan mencegah terulangnnya kelemahan & $100 \%$ \\
\hline 7 & $\begin{array}{l}\text { Penyampaian hasil audit internal ke LPPOM MUI dalam bentuk laporan berkala setiap } 6 \text { bulan } \\
\text { sekali }\end{array}$ & $100 \%$ \\
\hline \multirow[t]{2}{*}{8} & Ketersediaan bukti pelaksanaan audit internal & $100 \%$ \\
\hline & Total Persentase Keseluruhan & $100 \%$ \\
\hline
\end{tabular}

sumber: Data Primer (2019), diolah 
Tabel 11

Indikator pada Kaji Ulang Manajemen

\begin{tabular}{llr}
\hline \multirow{2}{*}{ No } & \multicolumn{1}{c}{ Indikator } & $\%$ Kesesuaian \\
& & $100 \%$ \\
\hline 1 & Kaji ulang manajemen dilakukan secara terjadwal setidaknya satu tahun sekali & $100 \%$ \\
2 & Kaji ulang manajemen di hadiri oleh manajemen puncak/MR & $100 \%$ \\
3 & Penyampaian hasil kaji ulang manajemen ke pihak yang bertanggung jawab & $100 \%$ \\
4 & Penetapan batas waktu dalam tindak lanjut hasil evaluasi & $100 \%$ \\
5 & Jika Ya, tindak lanjut hasil evaluasi sesuai dengan batas waktu yang sudah ditetapkan dan & $100 \%$ \\
6 & sesuai dengan hasil kaji ulang menajemen & $100 \%$ \\
7 & Jika Tidak, identifikasi penyebab kelemahan dan ditindak lanjuti & \multicolumn{1}{c}{ Total Persentase Keseluruhan } \\
\hline
\end{tabular}

sumber: Data Primer (2019), diolah

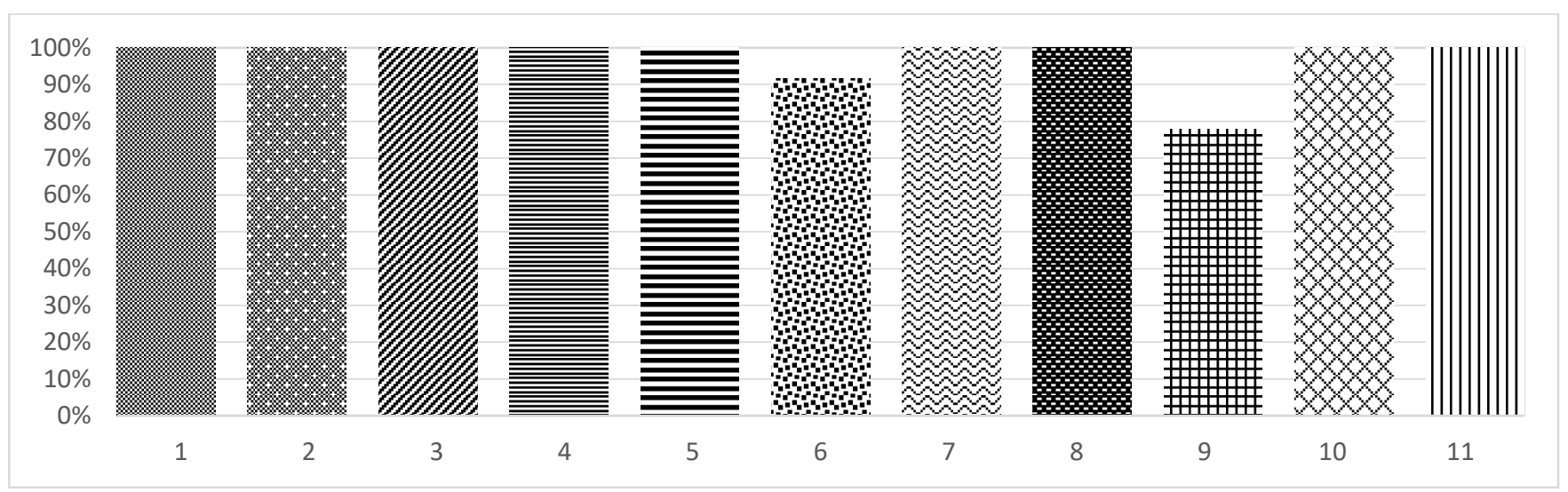

Gambar 1. Grafik hasil persentase kesesuaian: (1) Kebijakan halal; (2) Tim Manajemen Halal; (3) Pelatihan dan Edukasi; (4) Bahan; (5) Produk; (6) Fasilitas Produk; (7) Prosedur Tertulis untuk Aktivitas Kritis; (8) Kemampuan Telusur; (9) Penanganan Produk yang Tidak Memenuhi Kriteria; (10) Audit Internal; dan (11) Kaji Ulang Manajemen

\section{Kesimpulan}

Kesesuaian kriteria sistem jaminan halal di PT. Greenfields Indonesia telah sesuai dengan dengan pedoman pemenuhan kriteria sistem jaminan halal di industri pengolahan (HAS 23101) LPPOM MUI 2018. Persentase kesesuaian keseluruhan yang diperoleh sebesar 97,2\%.

\section{Ucapan Terima Kasih}

Ucapan terima kasih kepada Prof. Dr. H. Sugijanto, Ms., Apt. selaku ketua LPPOM-MUI Jawa Timur yang telah memberikan akses pengetahuan sistem penjaminan halal kepada penulis.

\section{Daftar Pustaka}

[1] Ahmad, MF. 2016. Menghubungkan persyaratan halal dan merek: pemeriksaan halal penyedia dapur terbang di Malaysia. Int. J. Supp. Kelola Rantai. Volume 7, Nomor 3: 208-215.

[2] Dewi, D. 2007. Rahasia di Balik Makanan Haram. Malang: UIN Malang Press.

[3] Lada, S. dan Amin. 2009. Memprediksi Niat untuk Memilih Produk Halal Menggunakan Teori Tindakan yang Beralasan. Jurnal Internasional Keuangan dan Manajemen Islam dan Timur Tengah. Volume 2: 66-67.

[4] Salehudin, I. 2010. Literasi Halal: Sebuah Konsep Eksplorasi dan Validasi Pengukuran. Jurnal Pemasaran ASEAN. Volume 2: 1.

[5] Usmiyati, S. dan Abubakar. 2009. Teknologi Pengolahan Susu. Balai Besar Penelitian dan Pengembangan Pascapanen Pertanian. Jakarta: IPB Press.

[6] [LPPOM] Lembaga Pengkajian Pangan, Obat-Obatan, dan Kosmetika Majelis Ulama Indonesia. 2018. HAS 23101: Pedoman Pemenuhan Kriteria Sistem Jaminan Halal di Industri Pengolahan. Jakarta: Balai Pustaka. 